OPEN ACCESS

Approved by:

Frontiers Editorial Office,

Frontiers Media SA, Switzerland

*Correspondence:

Qiutang Zeng

zengqt139@sina.com

Yucheng Zhong

zyc811029@126.com

these authors have contributed equally to this work

Specialty section: This article was submitted to Inflammation, a section of the journal Frontiers in Immunology

Received: 27 March 2021 Accepted: 29 March 2021

Published: 13 April 2021

Citation:

Yu J, Zhu R, Yu K, Wang Y, Ding Y,

Zhong $Y$ and Zeng Q (2021)

Corrigendum: Galectin-9: A

Suppressor of Atherosclerosis?

Front. Immunol. 12:686592.

doi: 10.3389/fimmu.2021.686592

\section{Corrigendum: Galectin-9: A Suppressor of Atherosclerosis?}

\author{
Jian $\mathrm{Yu}^{\dagger}$, Ruirui Zhu ${ }^{\dagger}$, Kunwu $\mathrm{Yu}^{+}$, Yue Wang, Yan Ding, Yucheng Zhong ${ }^{*}$ \\ and Qiutang Zeng * \\ Department of Cardiology, Union Hospital, Tongji Medical College, Huazhong University of Science and Technology, \\ Wuhan, China \\ Keywords: Galectin-9, atherosclerosis, T-cell immunoglobulin mucin 3, regulatory $\mathrm{T}$ cells, $\mathrm{T}$ helper cells
}

\section{A Corrigendum on}

Galectin-9: A Suppressor of Atherosclerosis?

By Yu J, Zhu R, Yu K, Wang Y, Ding Y, Zhong Y, Zeng Q (2020). Front. Immunol. 11:604265. doi: 10.3389/fimmu.2020.604265

In the original article, an author name was incorrectly spelled as Kuwu Yu. The correct spelling is Kunwu Yu.

The authors apologize for this error and state that this does not change the scientific conclusions of the article in any way. The original article has been updated.

Copyright (c) $2021 \mathrm{Yu}, \mathrm{Zhu}, \mathrm{Yu}$, Wang, Ding, Zhong and Zeng. This is an open-access article distributed under the terms of the Creative Commons Attribution License (CC BY). The use, distribution or reproduction in other forums is permitted, provided the original author(s) and the copyright owner(s) are credited and that the original publication in this journal is cited, in accordance with accepted academic practice. No use, distribution or reproduction is permitted which does not comply with these terms. 